\title{
JOURNALISM: NEW TRENDS AND ITS IMPACT ON RIGHT TO PRIVACY. COMPARATIVE ANALYSIS WITH SPECIAL REFERENCE TO INDIA
}

\author{
GIFTY OOMMEN 1
}

\begin{abstract}
Investigative Journalism is the act of the journalists which goes beyond simple reporting of events in the press. It involves newsgathering by taking an initiative to get the required information. The information in this case is not easily available. The extra effort taken for this type of newsgathering is termed investigative journalism. This method has gained great momentum in India. The need for this study is motivated by the fact that though India is a party to United Nations Declaration of Human Rights and the subsequent ICCPR 1966, it has failed to make Privacy a part of the Indian Constitution while Press is accepted as a fundamental right. Today the press in India like in other nations is under the control of multinationals, which use this as a weapon to dictate the government and the masses. It is in this scenario that this study becomes relevant, where due to lack of legislative intent the media has become an unbridled horse. This makes an individual vulnerable to media attacks and trials. This study will focus on Indian position and make a comparative analysis of the position in other nations which have a strong impact on Indian decision making and make suggestions to bring in importance for Privacy in India. The method adopted to collect data for this study is through literature survey and review.
\end{abstract}

KeywordS: UDHR; India; investigative journalism; privacy; press freedom; Press Council of India.

Investigative journalism is an act of press activism, which if conducted properly can do great help to any nation. This method of collection of news demands the journalist to be on his toes always and involves field work rather than seat work. It demands courage, knowledge of wide variety of things, support from the editor and the management and protection from the antisocial elements. Today this is the method of operation in prominent newspapers and television channels all around the world. To name a few are papers like The Guardian and the channel like British Broadcasting Corporation (B.B.C.). They are known for their newsworthiness and accountability towards the government and the public. In their vocation of news disbursement they follow high level of ethics and value system.

In India we do have some illustrations like the above, such as the Hindu and also the Times of India, where there is an effort on the part of the management and the editors to maintain the basic standards of newsgathering. But generally this is not a common practice among the media. We fail to find journalists undertaking field work and going through hardships to get news for the press in our country. In most cases the matter is obtained from police or the foreign reporting agencies or the local agents. This matter is then reported,

\footnotetext{
${ }^{1}$ Assistant Professor, Government Law College Ernakulam, India (giftyoommen@gmail.com).
} 
that is the reason many times the media when implicated in a case, finds taking as a defense, that the news was received from the police or other agents. This manifests their irresponsibility towards the trusting public. In this above process of newsgathering many a time ethics get eroded for gain of news and commercial gain. This is the problem faced in our country in the area of newsgathering. There is no mechanism as of now to effectively regulate this method of newsgathering especially when it comes to privacy rights. In the following paragraphs this conflict and the torts involved in it will be discussed taking cases from U.S, U.K and in this process the European trend will also be highlighted. After this, the problem as we encounter in India in light of the new technology will be elaborated, concluding with the possible suggestions and recommendations. These discussions will enable us to understand this conflict in depth in particular when it comes to privacy and its protection in India.

In India there is no legal pressure on the media to follow the code of ethics as enumerated by the Press Council of India in $2010^{2}$. As a result this freedom gives unwarranted freedom to the press to use any method whatsoever to get news. This could be in the form of sting operations using phone tapping, prostitutes, trespass and similar methods. It somehow gives a feeling to the public that the press is over the law, and their offences are forgiven while a private person has to face the law. Many such issues are dealt in this article in comparison with the democratic countries such as Britain and United States of America. Recently in Britain in August 2011, the media magnate Rupert Murdoch was questioned by the parliament on the matter of phone tapping of people which formed the source of their news. As a result he and his editorial staff had to suffer shame and court cases. This case also involved police officers, and as a result of all this and the public outcry, he had to finally close his tabloid 'The News of the World'. ${ }^{3}$

In cases where it is clear that the press obtained these information's through illegal means by sting operations, phone tapping and other mechanisms, though it might have some truth in it, this practice is not acceptable as it breaks other laws. Truth has to be investigated through legal means and not by any methods. The object and the method should both be legal. Investigative Journalism is not a license to do wrong but to be role models for the people of India as we progress towards greater goals. The media has done a lot of good through investigative journalism and its activism. Activism is normally demanded from the press, but usually this is not limited to matters which demand social interest. They have transgressed many a private people's privacy on the pretext of investigative journalism. Ultimately in some cases they find nothing worthwhile but the privacy is already violated. If the end result does no good to the public then some form of compensation should be given to the victim. This is not the only matter which is disturbing as, today the journalists are more technologically equipped in comparison even to the Police and the investigative agencies. This makes the life of a private person more

\footnotetext{
${ }^{2}$ Press Council.nic.in /Norms 2010 PDF, retrieved on 11/06/2010 at 7.20 PM.

3 'Lost our way, says disgraced tabloid', Indian Express dt. 11/7/2011 p.11.
} 
vulnerable as he is always under surveillance through minute cameras and gazettes and makes people beware in public and private places.

Though U.S. is the land of press rights as is emphasized in the First Amendment which forbids any interference in this right, and even though there is no explicit protection for privacy in its Constitution, still no excuse is given to press for committing torts in the process of newsgathering. It was stated in a Dietemann's case ${ }^{4}$, that the First Amendment gives the media no right to break laws with impunity, even if legitimate news is being published. This was a case against a reporter and a photographer. Jackie Metcalf the reporter and photographer William Ray went to house of a plumber, who was known as a doctor by the name of A.A Dietemann. They rang the bell and Jackie Metcalf acted as if she had a lump in her breast and as the doctor was conducting the examination, William took the pictures. Life magazine later published all these details along with pictures. Material was collected to be used to convict Dietemann as Mrs. Metcalf relayed her conversation with Dietemann through her transmitter in her purse. The plumber sued Time, Inc. for US Dollars 300,000 for invasion of privacy. The Jury recognizing that Dietemann was not having clean hands awarded the plumber only $\$ 1,000$ for invasion of privacy. This decision set the precedent that law breaking is not allowed in the process of news gathering.

Journalists are supposed to collect information which they can obtain through proper channel. Photographers can take photos from a public spot without going through strange acrobatics such as climbing or trespassing or using disguises.

Value System: Values and morals are to be preserved in news gathering. Ethics are to be followed if people want to trust the news media. They should win the trust of people through the value and ethics that they follow. In Cape Publications v. Bridges ${ }^{5}$, Hilda Bridges Pate had been kidnapped by her estranged husband at gunpoint. He took her to their former apartment and forced her to undress to prevent her from escaping. Then he shot himself to death. Police hearing the gunshot came and rushed her partially clad across the parking lot as she clutched a dish towel to her body. At that time she was photographed by this paper's correspondent. She contented that taking her photographs in semi clad form and consequently publishing it, violated her privacy. The Court considered it a newsworthy story and awarded no damages for her. Here the public came in because of the gunshot and press did nothing damaging towards her or for the process of collecting news.

Princess Diana \& Famous Personalities: The case of Princess Diana is a very perfect example of how press (paparazzi - Italian slang for a small annoying insect) can cause the death of a person. It was following of the press of Princess Diana and her

\footnotetext{
${ }^{4}$ Dietemann v. Time, Inc., 449 F.2d 245, 246 (9 $9^{\text {th }}$ cir. 1971).

${ }^{5}$ Cape Publications, Inc. v. Bridges, 423 So. $2 d 426$ (Fla. App. $5^{\text {th }}$ Dist. 1982), 8 Med. L. Rptr. 2535, 2536.
} 
companion in France that caused the car crash in which both she and her companion died. ${ }^{6}$ This is the way they behave with people; this shows how desperate they are to get hold of some news of great commercial potential. The risk involved is immaterial for them and they are least bothered about the damage done to the person involved, in this it happened to be a public person. In US, a similar case was of Jacqueline Kennedy Onassis, wife of John .F. Kennedy, late president of America, who had trouble with Ron Galella, a paparazzi who build up his career by taking their photos. He troubled Mrs. Onassis by following her almost everywhere and taking photographs literally giving her no private moment at all. It troubled her so much that finally an injunction was issued against him in 1975, protecting her privacy, which forbade him from approaching her within 25 feet or within 30 feet of her children ${ }^{7}$.

Some Legislative Measures: Paparazzi has been causing undue interference in the lives of public figures and private individuals. There was lot of pressure for legislation in US to bring press under control to cut off the supply of freelance photographers supplying intrusive photos to the press.

California has passed a statute imposing punishment for using of audio or visual recording devices on private property for collecting news. The media houses are also punished for buying these privacy invading recordings or photographs, even if the journalist providing the material are not employees of a media company ${ }^{\mathbf{8}}$.

Certain Exclusions: Except for governmental purposes, media was usually not allowed to intrude into private places in America. Certain exceptions have since been followed. In Ayeni v. $C B C^{9}$, Tawa Ayeni, wife of a man suspected of involved in a credit card fraud, was at home with her son Kayoda, a minor. At this time, the US Treasury Department agent came with a search warrant. Six federal agents went to the residence about 6. 00 p.m. Mrs. Ayeni clad in her dressing gown opened the door only slightly but they pushed their way in. Later at 8.15 p.m., the Treasury agent entered with a CBS news crew from "Street Stories". Mrs. Ayeni thought that they were part of the warrant team and never knew they were CBS employees. Later when she came to know that along with government officials, were press people. That is when she brought a suit against $C B S$. $C B S$ claimed immunity as they said they had the permission of the government agents. The Court allowed her lawsuit and declared that CBS had no greater right than that of a thief to be in the home to take pictures.

\footnotetext{
${ }^{6}$ U.K Law online -Princess Diana, Privacy Laws and press freedom in the United Kingdom, page 4. http://www.leeds.ac.U.K/law/hamlyn/diana.htm retrieved on June12, 2000 at 10.30.

${ }^{7}$ Galella v. Onassis, 487 F.2d 986 (2d Cir. 1973).

${ }^{8}$ California Civil Code Section 1708.8 (1998)

${ }^{9}$ Ayeni V. CBS, Inc; 848 F.Supp.362, 364 (E.D.N.Y 1994), 22 Media Law Reporter 1466, 1467.
} 
Technological Advances: Hidden cameras, wireless microphones and two way mirrors are just a few technologies in the hand of an investigative journalist to track down people in their private place. Cellular phones can create problems. Such was the case of Mr. \&Mrs. Martin ${ }^{10}$. The Martins were entertaining themselves with a scanner in their car, trying to pick up conversations coming within those radio waves at that time of the day. That is when they picked up this conversation by intercepting the signal from his cellular phone. This happened to be a discussion on phone between Representative Boucher and another person. Representative Boucher believed that the Martins had heard the Conversation. Once they recognized some of the voices, they tape-recorded it. This information got across through the New York Times to the Atlanta Constituency. Democrats and Republicans then exchanged counter charges. Republicans asserted that laws were violated by interception. The Martins were punished with a fine of $\$ 500$ for purposely violating a Federal Statute which forbids the use of a radio scanner to intercept radio telephone calls. Similarly, in Bartnicki v. Vopper ${ }^{11}$, the Supreme Court held that the reporters who were actively participating in illegal interceptions of electronically transmitted conversations were liable.

Fraud \& Disguise: When the Court finds a news agency guilty of fraud and trespassing, it has awarded high amount as punitive damages. Such was the case of Food Lion v. Capital Cities $/ A B C^{12}$ which happened in America. Here Dale and Susan were working undercover for Prime Time Live and had made false statements that they wanted employment, to get hired by Food Lion. They worked using tiny 'Jacket cam' or 'Lipstick' hidden cameras and recorders to gather information about the working of the organization. In the process they found some defects in the functioning, concerning hygiene. This matter was broadcasted and in response to the broadcast, Food Lion brought a suit against $A B C-T V$ alleging defamation, mail and wire fraud and trespass and also action against the 'employees' Dale and Susan for breach of duty of loyalty. Court held that they agreed that there is breach of duty of loyalty by the two employees and awarded damages for that but apart from that there were no punitive damages for fraud as it was a social need that there should be cleanliness in a food setup.

It was generally felt that food made in hygienic condition is essential for the society .As the government does not act to protect citizens on its own, it is felt in these cases, the reporters have to use such methods to get information from underground. Though there were other journalists who argued against it, criticizing the act of concealing identities or using hidden cameras on private property. Many legal scholars argue that liability in such cases can be overridden when a public good is served ${ }^{13}$. These matters have to be decided

\footnotetext{
${ }^{10}$ Adam Clymer, "Gingrich is heard urging Tactics in Ethics Case,” The New York Times, January 10, 1997, P.A1; Neil A. Lewis, "What the Law says on using scanning devices," The New York Times, January 16, 1997, p. A13.

${ }^{11}$ Bartnicki v. Vooper (U.S. S. Ct. 2001) See also Peavy v. WFAA - TV ( $5^{\text {th }}$ Cir. 2000)

${ }^{12}$ Food Lion v. Capital Cities/ABC, Inc., 984 F. Supp. 923 (M.D.N.C 1997). 25 Med.L.Rptr. 2185

13 "Self- Censorship at CBS", editorial in The New York Times, Nov. 12, 1996, Sec. 4, P.14.
} 
with utmost care, otherwise this privilege which is given in some exceptional case can become the general code of conduct for press and on the pretext of public good they can force all privacy barriers to open. Here in the above case the court the damage had already been done but all the same it was a genuine need of the society. At the same time the tort committed was not forgiven, therefore the journalists who enacted as employees were made to pay damages for breach of duty of loyalty towards the employer. It was a commendable decision especially because it happened in a country which is strongly in support of the press.

Overenthusiastic approach: In an award winning series of Huston Chronicle articles, reporter Nancy Stancill conducted a three month undercover investigation of Texas nursing homes. The photos showed the subhuman treatment rendered to elderly residents. This gave rise to state investigation ${ }^{14}$. So things do happen if press is vigilant and investigative. But the press, many a times, oversteps in every direction, treading the obvious bounds of propriety and decency.

Investigation-dangers in Law: Investigation precedes dissemination of news. In the process of newsgathering, the journalist should be well aware of the legal frontiers. He should not be allowed to take the law in his own hands. He cannot break the law concerning privacy, trespass and others. US Supreme Court has provided no immunity to press from liability for torts in the process of newsgathering. The Court has agreed that the Press need some protection during the process. Still keeping in view the Constitutional right to gather news, the Court went on to strictly limit its application by stating that the press has no 'Constitutional right of special access to information not available to the public generally' ${ }^{15}$. In this case, the Court held that a journalist has no privilege under the Constitution to withhold from jury, information which he has received in confidence from some source. The Court rejected the argument that the First Amendment should immunize newsgatherers from criminal liability. This case of Branzburg was reinstatement of the decision in Dietemann. ${ }^{16}$

Later, in Galella v. Onassis ${ }^{17}$, the Court took strong objection to the act of Galella, a paparazzi that used unconventional means to photograph Jacqueline Onassis and her children. Court held that as she was a public figure and had public activities, therefore the reporter's constant surveillance was unreasonable as it affected her activities, by affecting her mentally and emotionally. The court also stated that the First Amendment did not provide a 'wall of immunity protecting newsman from any liability for their conduct while gathering news.' Therefore it is established that press just like the general public will be

\footnotetext{
${ }^{14}$ Nancy Stancill, 'Deadly Neglect: Texas and its Nursing Homes’ (pts. 1-5), Hous. Chron., July 22-26, 1990, at AI, available in LEXIS, Nexis Library, Omni File. Westlaw. 71Tex.L.Rev.43 retrieved on 6/9/09 at 12.30 PM.

${ }^{15}$ Branzburg v. Hayes 408 U.S. 665 (1972).

${ }^{16}$ Dietemann v. Time.,Inc.,449F.2d245,246.

${ }^{17}$ Galella v Onassis, 487 F. 2d 986, 995 (2d Cir, 1973).
} 
liable for torts or crimes committed in the process of newsgathering. In the recent case of Cohen v. Cowles Media $\mathrm{Co}^{18}$, the Supreme Court denies that there is any Constitutional right to gather news.

The News Gathering Privilege: Though news gatherers might get some privilege, that is however limited in nature.

Therefore it is been understood from the above decisions that the most probable standard that a news gatherer should have is to establish that he had a reasonable belief that the plaintiff was engaged in illegal, fraudulent or potentially harmful activities before he decides to conduct the undercover fishing expedition. This privilege should not permit the press to employ subterfuge to pry into private lives or allow access to private homes. This should also not prevent the reporter from employing the privilege for a purpose other than that for which it was intended. Finally it should clearly serve common interest of the society that is to find the truth for which this privilege was exercised.

This qualified nature of the privilege seeks to protect individual privacy as well as freedom of the press. We need investigative reporters as they are watchdogs of the society. But the trouble with these watchdogs is that they sometimes attack innocent people also. Though not much fancied by people, an investigative reporter plays a valuable role in exposing societal ills and advancing reforms. The success lies to a large extent on the use of new gathering techniques, which does not pose a great threat to individual privacy.

Methods Employed for Investigation: The tools used in the process of newsgathering are many such as spying, phone tapping, prying, video and camera usage, disguise, lying pretence and persistence.

One such case was of Nellie Bly who gained notoriety as one of the earliest reporters in this field. In 1905, acting insane she got access to the women's asylum at Blackwells Island. During her investigation she exposed the human rat trap found there ${ }^{19}$. This being a matter of public evoking, it deserved merit. Today intrusive methods of news gathering threaten privacy more than ever before. New technologies make intrusion easier. Many agree that the increase in media intrusion is the result of increasing competitions for ratings and profits rather than an increasing desire to serve public. Hidden cameras make an excellent tool for uncovering serious misconduct but they can also be used for attacking a person's private life for the purpose of simply providing entertainment to the public.

A very good example of competition is the incident following Princess Diana's death, where a CBS executive was demoted because he did not immediately break into a

\footnotetext{
${ }^{18}$ Cohen v Cowles Media Co 501 U.S. 663, 669 (1991).

${ }^{19}$ Lyrissa Barnett Lidsky, 'Prying, spying and Lying: Intrusive news gathering and what the law should do about it' 73 Tul. L. Rev.173 page 4 retrieved from Westlaw on 6/9/09 at 1.00 PM.
} 
regular program, to report the news of her demise ${ }^{20}$. Similarly in President Clinton's case although Newsweek had early access to tapes of conversation between Linda Tripp and Monica Lewinsky, its editions did not make it public for need of additional verification. But within hours of their restraint, it was on the internet, by the Drudge Report, a source of unedited scandal mongering ${ }^{21}$. It affected the rating of the Newsweek, showing the degree of competition in this field. The above incidents prove that concern for individual privacy by press does not receive much reward for them.

Comparison U.S.A., U.K., INDIA: Intrusive newsgathering is another name for gathering news by the most innovative technology, where the gadgets used are very minute therefore difficult to find out whether you are under scrutiny of a camera or video or not. In U.S. the right to press is protected but not the right to commit wrongs for collecting news unless it is strongly in line with the social need of that time. While in U.K. the right to press is controlled under the Human Rights Act 1998, where privacy gets priority over press, which is the law in Article 8 of the European Union. While in India we have the Constitutional support for press under Article 19(1) (a) but there is no parallel protection for privacy in our Constitution. This is a big handicap as along with this there is no strong legislation to protect the citizens against the intrusive newsgathering. The law in India is very far behind the technological advancements of this time.

Most of this intrusive news gathering is done through ingenious surveillance technologies. Tiny cameras just larger than a lipstick case can be worn inside the dress and miniature recorders which can be concealed in a pocket is used for transmission of a news item to millions of people $\mathrm{e}^{22}$. There are instances where the reporter is absent while eavesdropping is taking place .For example the shotgun mike can pick up sounds as far as sixty yards away ${ }^{23}$. No wonder there is growing consensus among people to do something about intrusive news gathering. Thus investigative journalism has now being addressed as intrusive news gathering. A 1996 poll conducted by the Center for Media and Public affairs in the U.S. indicated that $80 \%$ of respondents thought the media invaded individual privacy and $52 \%$ thought the media abused their First Amendment freedom ${ }^{24}$. Any law designed to protect privacy must strike a proper balance between both First Amendment rights and realities as to how and in what instances the press exercise these rights. The question many a times arises in the life of an individual, when under scrutiny, is whether he or she had a reasonable right to Privacy. There are two principles governing expectancy of privacy. The first principle of video intrusion comes to play when the individual does not make an attempt nor has taken some voluntary step to expose himself or herself in public. Cases

\footnotetext{
${ }^{20}$ See Bill Carter, 'A Month late, the Fallout Hits’, N.Y Times, Oct. 8, 1997, at E8.

${ }^{21}$ Roger Bull, ‘ online and Loving it', Fla. Times Union, Feb 27, 1998, at D1 (www.drudgereport.com)

${ }^{22}$ Food Lion v. Capital Cities/ABC, Inc., 887 F. Supp. 811, 816 (M.D.N.C. 1995)

${ }^{23}$ Wolfson v Lewis, 924 F.Supp. 1413, 1424 (E.D. Pa . 1996)

${ }^{24}$ See John Hughes, 'solving the Media’s credibility problem,' Christian Sci Monitor, Apr.16, 1997, at 19.
} 
such as of Flora Bell fall in this category ${ }^{25}$. Here while in a fair with her kids, her dress just blew up in the wind. Her body was exposed from waist down and this happened to be photographed and published in the front page of the daily. She did not make any voluntary act to expose herself in public, it was simply by accident that it happened, and this caused embarrassment to her. Therefore the Court held that she had reasonable expectancy of privacy, even in public places. Flora felt 'embarrassed, self-conscious, upset and was known to cry on occasions'. Just because an incident happens in public, it does not forfeit the right to privacy of a person.

The Second Principle is applied when the object focused to be published cannot be seen ordinarily. It can only be seen by the use of visual enhancement device such as a video or spy camera placed in a portion where a person would not normally or reasonably be expected to be standing or sitting, then in those cases, there is definitely an expectation of privacy. People, who want to take photographs, do not normally lie down on shopping mall floors to take pictures of woman under their skirt. This cannot be achieved by ordinary process. It can only be done by using miniature video cameras attached to baskets which woman carry for shopping, provided by malls. This has become a big problem in the U.S. as their ordinary dress is skirts and frocks. In this case also, these women have expectancy of privacy as they cannot reasonably expect such intrusions to happen in public. This creates a great degree of insecurity to woman folk, if left unconcerned and unprotected by Courts.

Richard Brown of Gillett ${ }^{26}$, Wisconsin was alleged by police to be up skirt voyeur. In 1998, police alleged Brown of "hiding a video camera in a back pack, cutting a hole to expose the camera lens and then aiming it at the skirts of half a dozen female clerks who sat at tables while helping him. These women were working in a public location but still have a reasonable expectation of privacy that their private parts would not be videotaped. A series of such cases have been reported ${ }^{27}$. Technology has become so easily accessible and cheap. For as little as $\$ 100$, one can possess a dime sized camera, hide it and connect it to a video cassette recorder and become an anonymous gazer. For a few hundred dollars, voyeur may

\footnotetext{
${ }^{25}$ Daily Times Democrat v. Graham 276 Ala. 380 (1964). Flora Bell Graham, then a 44 year old housewife was attending the Cullman County Fair in Alabama in October 1961. As she was leaving the Farmhouse with her two young children, air jets blew up underneath her dress and 'her body was exposed from the waist down, with the exception of that portion covered by her panties. It just happened at that moment a photographer for the Daily Times Democrat snapped a picture of her and the newspaper in bad taste published the photo on its front page

${ }^{26}$ Video voyeurism, privacy, and the Internet: Exposing peeping Toms in Cyberspace - Clay Calvert, Justin Brown 18 Cardozo Arts Ent. L.J. 469, Page 9, retrieved on 6/9/09 at 1.30 PM.

${ }^{27}$ A Weymouth, Massachusetts man was indicted in July, 1999, for allegedly making videotapes of three babysitters when they undressed. He had a video camera in the bathroom. A man was arrested for using a video camera concealed in a gym bag to shoot up the skirts of the ten women at Jacob's field home of the Cleveland Indians baseball team. A collection of male student athletes from eight universities who claim they were secretly videotaped, filed a lawsuit in July 1999 - they were videotaped at urinals, in showers etc. Id 22, page 4.
} 
go wireless, transmitting undetected images to either a monitor or recorder ${ }^{28}$. In most of these images, the victim's face and identity are readily discernable. E.g. video images taken in a locker room, bedroom or bathroom - When these images are published or posted on the wide web, these constitute violations of privacy $^{29}$. These can be posted on news web sites by reporters or by private individuals. These types of offences are yet to be seen rampant in India, therefore we need to keep pace with the problems of technology in other developed countries to be vigilant in the area of law making.

Even in the United Kingdom, such offensive newsgathering is not entertained by the Courts. In British radio DJ Sara Cox's case in $2003^{30}$, where she was photographed naked in her Jacuzzi on her honeymoon. The photograph was taken by a long lens from a boat offshore and then published in The People newspaper. The Court awarded her an amount of 50000 pounds $^{31}$. Similarly, Sienna Miller was also given 37500 pounds in 2008 for the unauthorized photograph in The Sun wearing a costume in a closet set of the film Hippie Hippie Shake ${ }^{32}$.

A most interesting case was of Mosely v. News Group Newspapers ${ }^{33}$. Here Max Mosely was president of the governing body of Motor Sport worldwide. He had been filmed using a secret camera, while engaged in a sexual activity with five dominatrixes in the basement of a private flat. Later an article along with the photograph was published on $20^{\text {th }}$ March 2008 on the Newsgroup Newspaper website. He sought injunction but within days there had been 435000 hit on that website. So the Court stated that injunction would no more help, though damages were given. Here it shows the maturity of the courts, as they understood the complexity of online publications, and also therefore the failure of injunction in such cases. Therefore they awarded damages for each hit, and this could be executed in Britain. Thus it became a very expensive coverage for the paper, which had used intrusive methods for taking these photographs. Just because a celebrity shows bad behavior gives no excuse to reporters to go ahead with intrusive search into the very private parts of their lives. An analysis will show that U.K. is stricter towards reporters when it comes to intrusive news gathering. They are running in consensus with the European Union, which is strongly in favor of privacy.

The U.S. faced the television and video problem in the Court in Estes v. Texas ${ }^{34}$ for the first time. In this the Court declared the purpose of the Sixth Amendment's provision

\footnotetext{
${ }^{28}$ Id. at p. 5.

${ }^{29}$ Id. at p. 13.

${ }^{30}$ Melville Brown, Amber 'Camera shy - the Interaction between the camera and the law of privacy in the UK’, International Review of Law, Computers and Technology, 2008 22: 3, 217. http://dx.doi.org/10.1080/13600860802496400. Retrieved on 12/6/09 at $1.40 \mathrm{pm}$.

31 Ibid.

32 ibid.

${ }^{33}$ Mosely v. News Group Newspapers (2008) EWCH 687 (QB)

${ }^{34}$ Estes v. Texas, 381 U.S. 532 (1965).
} 
for public trial. While analyzing the right of the press to televise Court proceedings, the Court determined that the press has the same privilege as the general public to access the Court room ${ }^{35}$. The Court specified that the concept of public trial guarantees that the defendant is "fairly dealt with and not unjustly condemned" ${ }^{36}$. Later in Sheppard's case ${ }^{37}$ the Court looking at the circumstances including the failure of the trial Judge to take care against the influence of pretrial publicity, held the defendant's due process right for fair justice was violated. Pretrial publicity is trial by the media even before the case comes for hearing, regarding its analysis of the case. In the U.S. as the cases involve jury; it tends to influence the mind of these ordinary people of society who form the jury. They have no basic training in judicial process, thus they might give their decision under a preconceived notion .This affects the criminal defendant's right to a fair trial by influencing public opinion thereby affecting the mind of Jurors ${ }^{38}$. In U.S.A., where there is Jury trial, pretrial reporting can have a detrimental effect on justice.

The problem dealt here is only peripheral as needed for the discussion. In U.S.A. Contempt of Court is not strong and stringent as in UK and India. This is because of the First Amendment, which guarantees freedom of information and the Sixth Amendment, which projects public trial in cases. These provisions if read together gives rise to a confusion in the mind of Judges, whether to protect pretrial reporting or not. This right of presence of media at a Criminal trial is not expressly articulated in the Constitution, but there is some constitutional protection given to $\mathrm{it}^{39}$. But this right is subject to reasonable restrictions. As the constitution is silent on restrictions on media therefore in some cases of impairment of justice the courts are forced to either terminate the proceedings or pass gagging orders. These gagging orders ban the media from reporting the case till the order is removed by the court.

One of the earliest in this line is the 1946 Federal Rule of Criminal Procedure $53^{40}$, which prohibits Courtroom photographing and broadcasting in the Federal District Court ${ }^{41}$. However the judicial conference of the United States in 1990 did resolve to permit televising civil proceedings at the trial and appellate levels. But it prohibited any similar ${ }^{42}$

\footnotetext{
${ }^{35}$ Id.at p. 540.

${ }^{36}$ Id.at p. 538-39.

${ }^{37}$ Sheppard v. Maxwell, 384 U.S. 333, 335 (1966).

${ }^{38}$ Gannett Co., Inc. v. Depasquale, 443 U.S. 368, 378 (1979).

${ }^{39}$ Richmond Newspapers, Inc. v. Virginia, 448 U.S. 579-80 (1980)

40 'An analysis of the legality of Television Cameras Broadcasting Juror deliberations in a Criminal case' by Daniel H. Erskine, Esq. [FNa1] 39 Akron L. Rev. 701, 2006 retrieved from Westlaw at 1.00 PM on 7/9/09. Page 6

${ }^{41}$ Id. Fed. R. Crim. p.53. "Except or otherwise provided by a statute or these rules, the Court must not permit the taking of photographs in the Courtroom during judicial proceedings or the broadcasting of judicial proceedings from the Courtrooms”.

${ }^{42}$ Ibid.
} 
broadcast of criminal trials. Therefore both houses of the U.S .Congress have proposed legislation to permit discriminatory televising of federal proceedings ${ }^{43}$.

The English Courts however have been very strict about media interference through video or otherwise during the trial stage. An act of Parliament was brought in called the Criminal Justice Act of 1925. This Act made publication of any portrait of any person, in a court an offence. ${ }^{44}$

The Contempt of Court Act 1981, in England also permits criminal prosecution if any information divulged at trial is published. ${ }^{45}$ In India we do not go to this extend. Here in India fair reporting of information is allowed but in England no reporting of information is permitted. One would virtually remember the case of toddler Baby $P$., who was brutally killed by his own mother and her lover ${ }^{46}$. The Court did not release the names of the Couple and their background till final decision came in. This was in keeping with the protection afforded to their identity. In $R$ v. Loveridge ${ }^{47}$, the Court of Appeal did not allow the filming which took place at the Court, as it contravened statutory law. Thus it can be clearly stated that English Courts are against videos being used in Court.

The situation in the USA is fundamentally different, where the fight between fair trial and press still continues. The O.J. Simpson trial is a very explicit example in which press over seeded the right to have a fair trial ${ }^{48}$. While in USA, there are no deterrent sanctions to prevent prejudicial publicity, in England and other Commonwealth countries like Canada, Australia and New Zealand there are heavy penal sanctions for the Publishers of materials that may interfere with the due course of justice ${ }^{49}$. The judgment of the European Court of Human Right ${ }^{50}$ led to the 1981 enactment of the Contempt of Court Act.

It seems at the adversarial systems it is based on the idea of openness of the judicial proceedings. They believe that justice should not only be done but should appear to have

\footnotetext{
43 Ibid.

${ }^{44}$ Criminal justice Act of 1925 - section 41 (1).

${ }^{45}$ Contempt of Court Act 1981- section 6 (c).

46،Woman, boyfriend who tortured baby named', The New Indian Express, August 12, 2009 Cochin, p 11.

${ }^{47}$ R. v Loveridge. 2 Crim. App. R. 29 (2001).

${ }^{48}$ http://en.wikipedia.org/wiki/O.J. Simpson murder case, retrieved on $24^{\text {th }}$ June 2010 at 10.30 am.

49 'The Court of Public opinion: The practice and ethics of trying cases in the Media' by Kathryn Webb Bradley. Cite as (71 - Fall Law \& Contempt Probs.31). Page 3 retrieved from Westlaw at 1.30 pm on 7/9/09.

${ }^{50}$ Sunday Times v United Kingdom. App. No. 6538/74, 2 Eur. H.R. Rep. 245 (1979). It was a case in which a drug was responsible for damage to many unborn children, and while this case was pending in the court, the Sunday Times came with an article, which accused the manufacturers of the drug of negligence. The case went on to the European Court. The Court concluded that the interference did not correspond to a social need sufficiently pressing to outweigh the public interest in freedom of expression. And therefore the article was protected. This U.K. Government responded to this decision by the enactment of the Contempt of Court act 1981. This Act took account of the ruling of the European Court and was also influenced by the 'prejudgment test'.
} 
been done. Therefore they do not like secrecy. While in the inquisitorial system of trial, they cannot get rid of some sort of secrecy. This is so regarding the preliminary stage while the main hearing is open to the public ${ }^{51}$.

Indian System of Newsgathering: Indian journalists have been keeping pace with press around the world. Indian press has been instrumental in bringing many matters into public stage. Many corruption cases have been reported and brought to the forefront by the press and other media.

But in the process of news gathering many laws have been violated by journalists. Enthusiasm is a good thing, but it should not hurt any person until it is of such social importance. This barrier can be crossed only if the mass media shows valid grounds for breaking it, for reasons considered by public and government as justified. This justification can only be allowed in terms of social interests such as security, anti-corruption, peace, harmony and respecting the ethics and sentiments of people.

Sting journalism which works on the principle of obtaining information by deceit involves impersonation, lying and cheating, not to mention risk. It also requires clever marketing. E.g. the Lakshman tapes (Tehelka). One of the main accusations against Tehelka.com was that the organization used deceptive means to make a quick name for itself in which it succeeded. But many did not approve of the methods used. Sting journalism should understand that it is not easy to always justify violation of law. A hidden camera or microphone used to surreptitiously record information is violation of privacy. Use of drugs or call girls to take out information or trap officials is a crime ${ }^{52}$. Similarly, in the Bofors case, Justice J.D. Kapoor observed, while pronouncing the verdict that the case at hand is a good and nefarious example which manifestly demonstrates how the trial and justice by media can cause irreparable, irreversible and incalculable harm to the reputation of a person and shunning of his family, relatives and friends by the society. The Court said that such a person is ostracized, humiliated and convicted without trial. The Court cited the case of Punjabi pop singer Daler Mehndi whose discharge was sought in a human trafficking case after his humiliation and pseudo trial through media as they (police) have not been able to find the evidence sufficient even for filing the charge sheet ${ }^{53}$

\footnotetext{
${ }^{51}$ See European Convention, Supra 28, Article 6(1), which states the principle that "judgment shall be pronounced publicly" but admits that the press and the public may be excluded from all or part of the trial in the interest of moral, public order or material security in a democratic society, where the interests of juveniles or the protection of the private life of the parties so require, or to the extent strictly necessary in the opinion of the Court in special circumstances where publicity would prejudice the interests of justice.

${ }^{52}$ Sunil Saxena 'Candid Cameras, call girls, bribery. Is sting operation crossing the Lakshman Rekha?' New Sunday Express, March 14, 2004, page 17.

${ }^{53}$ The Hindu, Thursday, $5^{\text {th }}$ Feb 2004. http://www.hindu.com/2004/02/05, retrieved on 30/609 at $10.50 \mathrm{am}$. It was a case about accusing former Prime Minister Rajiv Gandhi of receiving bribe from an Italian company for giving them the placement order for Bofors.
} 
Disturbing Realities: There have been many instances of media reporting which has resulted into nothing positive except cause pain and hardship to the person tortured by the media. In 1980 Lindy Chamberlain, in Australia, was tried for the murder of her baby. She was convicted and later released on fresh evidence that a dingo (a wild dog) had committed the act. In fact she had stated that in her case. Bit later a motion picture 'A cry in the Dark' depicting her story was made, enacted by actress Meryl Streep ${ }^{54}$. This public depiction of her case by the media caused her great agony. One can imagine the pain and agony undergone by a mother who lost her baby, got accused for it and finally given a public exposure to world for no fault of hers. This was an act of great irresponsibility on the part of media.

In USA, investigations were made into biologist Steven Hat fill for allegedly sending anthrax viruses through the mail as a terrorist attack. The media gave this publicity. Though this investigation brought no concrete evidence against him, the media exposure resulted in causing severe tarnish to his name and destroyed his career ${ }^{55}$. All this was caused due to the media outcry and exposure. The Bofor's scandal also came to nothing except it caused tarnish to the image of Rajiv Gandhi and his family.

The ISRO espionage ${ }^{56}$ case in Kerala in which the media falsely framed two scientists in an espionage scandal was finally laid to rest by the Supreme Court of India on April 29 1998. The CBI found no genuinely in the case. This was looked at by the court in bad taste and media generated, and projected the press as very irresponsible. This is another way of investigative journalism used by the media, to excite the people by giving them some spicy information, to think and imagine by which they malign the person focused and at the same time increase the circulation of the paper.

The statement made by the media regarding lawyer Ram Jethmalani when he decided to defend Manu Sharma, a prime accused in a murder case. He was subjected to severe criticism for defending the accused. A senior editor of the television channel, CNNIBN called that decision of Jethmalani, an attempt to "defend the indefensible”. The press complained that it was not fair that a prominent lawyer like Jethmalani should appear for the accused and that only an average lawyer should argue for the state ${ }^{57}$. Again this is bypassing into the private right of an advocate, as to, for whom he should argue.

\footnotetext{
54 Trial by media - wikipedia.org http://en.wikipedia.org/wiki/Trial by media - retrieved on 3/6/09 at 10 am.

55 Ibid.

56 'ISRO Spy case. Requiem for a Scandal’ by R. Krishanakumar, Frontline vol. 15::No 10::May 09-22, 1998. http://www.hinduonnet.com/fine/f11510/15101140.htm retrieved on 1/3/2010at 6.30 pm. This was a case involving two scientists working in Indian Space Research Organization, Thiruvanandapuram, who were accused of espionage with official documents. This case was completely framed by the media. Finally investigations found no evidence to prove their involvement in any espionage activity.

57 Trial by media: prejudicing the subjudice. http://www.rminlu.ac.in/content/devesh article by S. Devesh Tripathi $2^{\text {nd }}$ year BA, LLB (Hons) RMLNLU Lucknow - retrieved on 5/6/09 at 10.05 am.
} 
Similarly, in Mohammed Afzal, of the Parliament attack case of December 2001, the media started its own trial shortly after his arrest - here the media played an excessive and negative role in shaping the public conscience. The role of court was taken over by the media, even before he was tried by the Court. The opinion of the media was already fixed, that he is a terrorist and needs death sentence. This sort of evidence and discussions shown on the small screen can definitely prejudice the mind of an ordinary person. Along with Mohammed Afsal his co-defendant S.A.R. Geelani was also sentenced to death despite lack of evidence and the media portrayed him as a dangerous and trained terrorist. But later the Delhi High Court overturned his conviction, which was a blow to the impression given by media of this person. The court described the prosecutions case as 'absurd and tragic's8. This gives a very clear idea of the preconceived notion that the media projects to the people of this country long before the process of court of law is over. Therefore when the decision comes in contradiction of the view given by the media, public tends to think as to whether judges are corrupt and biased.

Disturbing photographs: Similarly the carelessness of press is not just evident in writings alone, this is also seen depicted through photographs, etchings etc. Morphing is a technique whereby a person's face is put on the body of someone else. It is a process which leaves behind no tell-tale mark, especially if transferred to another computer, which reads it as an original file. This is a malpractice done by the media houses. This method is in clear violation of the identity and individuality of the victim, which forms an integral part of their privacy. The photograph of south Indian film star, khusboo, was morphed in such manner. Then it was the Rajya Sabha member and CPM leader Brinda Karat. In both the cases, morphing was done by Maxim, the top selling international men's magazine that was given license to start publication last year ${ }^{59}$.People do not even think of filing a case, as the courts just ask the media to give in their apology, the loss of reputation and the cost of litigation does not seem much to the courts.

No media house should be allowed to change or replace parts of a photograph. This is a moral wrong, especially if it demeans a public figure. In 2006, the discussions came in Mumbai Mirror of former Kerala minister, P.J. Joseph ${ }^{60}$. It was concerning the allegation of a co-traveler who is a lady, regarding some physical contact on her body by the minister while traveling in a flight. But the picture shown was of another Minister K.M. Mani and not of P.J. Joseph. Transmission of wrong pictures in this way can cause stigma for an innocent person and is not good for press reporting. This behavior of the media is in bad taste, but unfortunately all this just goes on with no remedy been taken.

\footnotetext{
${ }^{58}$ Id. at p. 51

${ }^{59}$ Sunil Saxena 'Picture Imperfect', Indian Express dated 19/03/2006

${ }^{60}$ Mumbai Mirror dated 20/8/06.
} 
Press Council of India: ${ }^{61}$ This body established in 1978, has been given a responsibility to prevent adverse remarks against the press. The PCI provides for rules for scrutinizing the work of Journalists. These rules include provisions that reporting should maintain accuracy and fairness. ${ }^{62}$ It should be subject to prepublication verification ${ }^{63}$. The press has been asked not to intrude or invade the privacy of an individual unless outweighed by genuine overriding public interest. ${ }^{64}$ Though the PCI has its rules for maintaining the equilibrium between public needs and private privileges, it is not found to be doing its job effectively. They normally end up asking the newspaper to apologize or retract the damage causing article or publish a rectification. These wrong doers are not made to give any compensation or damages to the victim. These newspapers do not suffer any heavy damages as there is no element of deterrence in the punishment given for violating the rules/orders of PCI. Hence, these wrong doers, instead of becoming more vigilant in future, perhaps become more comfortable as they know the extent to which PCI would go in punishing them. In the case of an article in Indian Observer ${ }^{65}$, named 'Tragedy of the Chastity Belt', the PCI upheld the complaint against it. The article was regarding discussion of the need and use of chastity belts for women to preserve their chastity. The complaint was that the article was grossly obscene and was likely to arouse desires and sexually deprave the reader's thoughts. This complaint was raised by the Delhi Administration. The PCI simply warned the editor against such writings, which clearly reflect the power to which the PCI can exert pressure on the press. It is easy to acknowledge that this warning by PCI will have no deterrent effect on the Indian Observer. Apart from warning, admonishing and censuring, PCI also has criminal contempt powers. These powers are used to restrict the publication of prejudicial media reports but this is very rarely used. PCI can only exercise its contempt powers with respect to pending civil or criminal cases ${ }^{66}$.

Recent Cases: To cite the regression of ethics through the process of investigative journalism is so evident in the recent times, it seems that the press reporters and publishers have taken their freedom for granted. If no space is given for putting reins on them, then it is definitely a lapse on the part of the legislature. Sr. Sephy's petition in the High Court demanding an inquiry into the incident of leakage of visuals of narco analysis test tapes was elaborative of this government lapse. These visuals were telecast by Malayalam news channels. Such incidents proved the need for Courts to issue directions to CBI not to divulge details of an enquiry to the public or press. Therefore as a result Justice Hema of the High Court of Kerala stated that the courts should not be carried by the 'media trial' and

\footnotetext{
${ }^{61}$ Herein after referred to as PCI.

62 Swati Deshpande, 'Media and Law -A Reporter's Handbook', published by AMIC India and UNESCO 2006, pg.190.

63 Ibid.

${ }^{64}$ Ibid.

${ }^{65}$ Report of Press Council of India 1969 p. 10.

66 Trial by Media - Human Rights Features, http://www.hrde.net/sahrde/hr features, retrieved at 10.39 am on 9/6/09.
} 
that courts should, and can, act only on the basis of case records. She said the 'Media has pronounced the verdict already without looking into any of the facts. The public has joined hands, being carried away by the various publications effected through media, which do not contain the bare true facts which are revealed by the case records. A demociean sword of a threat of ill repute is held over the head of any Judge who may ever dare to lift his/ her pen and write or speak any thing contrary to the 'media public verdict' which is already pronounced .The Courts can go only on the basis of the facts covered by the case records. ${ }^{67}$ The Ambani's issue also needs to be mentioned, where they were indicted by a website as being behind the death of former Chief Minister of Andhra Pradesh, late Y.S. Rajasekhara Reddy ${ }^{68}$. This simply made front news on the basis of vague reports in a couple of vernacular channels that a Russian online biweekly tabloid - exiledonline.com carried a report that the death of YSR was not an accident but a result of a conspiracy hatched by the 'Ambani brothers' ${ }^{69}$. This news ultimately held no ground as they could not substantiate its conclusions.This shows the audacity of broadcasting news without any verification regarding its truth and authenticity

Less than 24 hours after this vernacular channel TV5 put out this report, the police arrested its Senior Executive Editor and input Editor. But the damage was already done as large scale disturbance ${ }^{70}$ took place in the night causing loss to Reliance Ltd and State Government of Andhra Pradesh. Recently T.P Nandakumar, chief editor of crime magazine was arrested on charges of defamation by Alexander, for publishing a defamatory article against him in the online edition of the magazine. It was stated that Nandakumar demanded money for not publishing the article. ${ }^{71}$ Jammu \& Kashmir witnessed a media gag in fear of terrorist attacks; as a result there was a total 'blackout of news in the local newspapers. ${ }^{, 72}$ This was to maintain peace on the valley.

Three photo journalists were summoned by the police for taking photographs of President Pratibha Patil on a Goa beach. The media had been asked to keep away from her. This was countered by the president of the Photo Journalists Association Goa, who stated that beach is a public 'place and they have every right to be there. ${ }^{73}$ If this is guarantee of privacy for a President who was simply relaxing and not on any duty on the seaside, then the status of privacy would be really pathetic for a common man of this country .It was real sad to hear Jammu \& Kashmir Chief Minister Omar Abdullah lamenting at the press report of his separation from his wife and his future plans. He was really grieved while stating that 'I believe my family and I are entitled to that privacy. At this point my concern has to and

\footnotetext{
${ }^{67}$ Sr. Sephy and others v. Union of India and another 2009 (1) KHC 121.

68 ‘Ambanis behind YSR Death?', The New Indian Express ,(Cochin) dt. 8/1/2010, p. 1.

${ }^{69}$ Ibid.

${ }^{70}$ Report that came to bite them, The New Indian Express, dt. 9/1/2010, p. 1.

71 'Crime editor arrested', The New Indian Express, dt. 4/7/ 2010, p.9.

72 'PDP condemns media gag', The New Indian Express, dt. 11/7/2010, p.9.

73 'Photo journalists summoned for snapping President', The New Indian Express, dt. 6/1/2011, p.10.
} 
will remain my young sons who do not deserve to see themselves splashed across the news channels and pages of newspapers in this manner. ${ }^{74}$

Conflicts: Media Trial has now become the focus of many discussions. Media trial is often conducted in two different realms. First by the traditional publishing media houses, which disburse news items through newspapers and magazines? The second by the more elaborate, quick and effective means; through the electronic media.

Faster the technique of transmission of news, faster the damage it can possibly do in the process. Therefore, transmission through electronic media demands a greater need of caution in regards to electronic media. Unfortunately, unlike the print media, electronic media has no regulatory body ${ }^{75}$, was stated by former Justice G.N. Ray. He tried to bring it under the PCI, and brought it to the notice of the government, but nothing materialized. In his lecture he states that the mechanism available against Electronic media is only through Contempt of Court Act 1981 regarding subjudice cases and secondly through the usual Article 21 of the Constitution of India regarding other matters. Justice Ray observed that it will be appropriate if the electronic media is regulated without any loss of time. He recommended the constitution of a Media Commission for in-depth study of various aspects of functioning of both electronic and print media ${ }^{76}$. Presently we have only the mechanism of restricting the channel or prohibiting it under the Cable Television Networks (Regulation Act) 1995, by the Central government. The reasons would be in the interest of public order, decency or morality. But this is only a general restriction; no private remedy is available for any particular victim ${ }^{77}$. Lately the Ministry of Information and Broadcasting has banned Fashion TV (FTV) for 10 days from March 10 till 21, 2010. This has been for showing bare breasted women in September $2009^{78}$. This punitive action is not at all found effective.

The situation that we are encountering in India is similar to the statement made by Justice Black in his dissenting judgment, "there comes a time when even speech looses its constitutional immunity. Speech innocuous one year may at another time fan such destructive flames that it must be halted in the interests of the safety of the Republic. When conditions are so critical that there will be no time to avoid the evil that the speech threatens, it is time to call a halt otherwise free speech which is the strength of the nation will be the cause of its destruction [...]", in Dennis v. US ${ }^{79}$. This is what is happening in the sphere of media freedom. Since the press has been using this freedom in an irresponsible manner, it has been gradually losing its authenticity and along with it the trust that people

\footnotetext{
74، Stories about Remarriage are false: Omar’, The New Indian express dt. 16/9/ 2011, p. 7.

${ }^{75}$ Law Lecture by Chairman, Press Council of India on August 31, 2008 at Bhubaneswar, organized by Gora Chand Patnaik Memorial Trust.

${ }^{76}$ Ibid.

77 The Cable Television Network (Regulation) Act, 1995, ss. 19 and 20.

78 'Fashion TV bares all, gets banned.' The New Indian Express, dt. 12/3/2010, p.1.

${ }^{79}$ Dennis v. US (1951) 341 U.S.
} 
have had in them through the years. Over and above, they are violating the right to freedom of speech and expression, invariably, and this needs to come under a check otherwise this freedom will cause destruction as visualized by Justice Black in his above dissenting judgment. The Chairman of the Press Council of India Justice (retd.) Markandey Katju, stated that the argument that media was also a business and must give the people what they want "is degrading the media. The media is not an ordinary business that deals with commodities, it deals with ideas." He said that the intellectual level of our people is very low. The media should not go down to that level. He said a large section of the media was diverting the attention from the real issues, and giving more importance to entertainment news and superstition rather than dealing with genuine issues of social development, which is the actual role to be played by the media ${ }^{80}$.

Position of Press - Subjudice matters: It is very important that the press does not lose the confidence of the society. Thus the Fourth Estate in a democracy operates along with legislature, executive and the judiciary within the framework of the constitution. In the wake of the amendment of the Contempt of Courts Act 2006, wherein truth has been accepted as a defense in Contempt proceedings ${ }^{81}$, for subjudice matters, precaution has to be taken by the investigative agencies that matters are not revealed to the media. Truth being a defense, the media is bound to further exploit the information received if it is the truth, unconcerned by the damage it can make on the privacy aspect of an individual. The judges have to yet to fix the parameters of the truth in each and every case. Every truth cannot be a defense if it runs the risk of destroying a person's life though he might have repented of it. Unless and until, it serves a public interest to reveal the truth, truth as a mere defense is calling forth controversies.

The Court should decide which truth should be entertained and the qualification of truth which can be allowed as a defense in case of contempt of court proceedings. The media involvement in criminal administration had received in-depth consideration of the "Committee on National Policy of Criminal Justice" in the wake of the sting operations and trial by the media. The Council opined that unless there is substantial risk of serious prejudice to the course of justice, there should not be restriction or prohibition on the coverage of criminal proceedings ${ }^{82}$. In 1994 detailed principles were drawn up since known as 'Madrid Principles' on the relationship between Media and judicial independence, at the conference organized by the International Commission of Jurists ${ }^{83}$.

\footnotetext{
80 'Katju: media must provide leadership to society', The Hindu, dt. 6/12/2011, p. 10.

${ }^{81}$ The Contempt of Court (Amendment) Act, 2006 - section 2 substituting section 13 of the Act.

${ }^{82}$ Address by Justice (Retd.) G.N Ray, Chairman - Press Council of India at Vignayan Bhavan, New Delhi, on $29^{\text {th }} \& 30^{\text {th }}$ March 2008 on the inauguration of two days workshop on 'Reporting of Court Proceedings, by Media and Administration of Justice’ organized by Supreme Court Legal Services Committee, Press Council of India and others.

${ }^{83}$ Ibid.
} 
Responsibilities of the Press: Courts at large gives protection to a free press. Right to freedom of information is the password of these times. The role of media is widely recognized today. The responsibility of the press however is yet to be appreciated by the press. People have started wondering as to whether the press today operates just like any other business. Ownership of media has increasingly caused apprehension as to whether this commercial aspect may influence the opinion and ethics of the editorial board. Still amidst all these concerns, law and judiciary still continues to protect freedom of press and consider it as an important part of freedom of speech and expression. Lately, the issue of 'paid news' was reported in the Rajya Sabha ${ }^{84}$. This concept of paid news has been there for some time, but it came to limelight when during last elections advertisement in the form of regular news was given in newspapers. This is bound to confuse the readers as they believe these campaign news items as genuine news. These 'paid news' has been paid for in terms of huge money just like an advertisement, while the regular news is genuine information for which no payment has been paid. This is taking the privilege of this freedom of press too far, due to the impact it creates on the masses. The opposition asked the government to take stringent action against any media house or politicians indulging in it. Leader of the opposition in Rajya Sabha, Arun Jaitley, advocated appointment of a regulator to deal with these matters. He described the Press Council of India as a toothless wonder. He emphasized that "the reader or viewer has the right to honest, unadulterated news, which is being denied to him. He is not even being informed that the news is motivated by monetary considerations”. CPM leader Sitaram Yechury said that corporatisation of media houses had led to this menace and it was against parliamentary democracy $^{85}$.

CONCLUSION: Though Indian system by and large follows the combination of British and the U.S system, it tends to tilt towards the broader decisions of the U.S Supreme court. As the Indian Constitution also does not encompass the right to privacy while Press freedom is made a Constitutional right just like in the U.S, therefore it is important that we in India do not follow the system as in U.S. It could be concluded that we in India cannot have a press uncurbed and free. The Courts are still being liberal with the press so as to develop a strong freedom of information system in India. Today, along with all this, we also have the right to Freedom of Information Act 2005, which gives right not just to the press but to each and every individual to break through the veil to get information of persons in power, institution and government. When the right to information is raised to a high pedestal then it is time that the corresponding duty to protect the privacy of its citizens is also given a respectable pedestal. To day media freedom cannot be mistaken for a world without secrets. In fact this is a dais; commercially manipulated to bring out man woven stories, which is constitutionally protected. It was a routine affair to distribute pens, notepads and folders during press conferences. Then it jumped from these free samples to bigger presents like gold, vouchers and holidays. Political reporting was paid in covers

84 ‘Govt. urged to crack down on 'paid news’ - The New Indian Express, dt.6/3/2010, p.7.

${ }^{85}$ Ibid. 
having rupees 2000 or more. As this political reporting increased in journalism the lines of separation became blurred. Niira Radia, the popular lobbyist was simply doing this, the journalists involved in the Radia tapes were passing messages between corporates and the government to get certain people into the cabinet and for other reasons. ${ }^{86}$ This is what the media is doing but in a different field, dealing with people and facts to manipulate persons in power, exposing their private facts for the media's profits and benefits. The elements of public interest versus privacy should be the test for deciding a case in favor or against a media reporting. The Courts in India should determine the parameters of both these rights. The media houses should be asked to open its doors to give information to the public under the Right to Information Act to ascertain whether the proper process of verification has been followed to prove the truth in the reported matter. They should have an active Ombudsman which accepts complaints from the public, adjudicates over it, resulting in rendering apology, penalization and awarding compensation to the victims of their reporting. The object of Ombudsman should be targeted towards winning the confidence of the victims and the public. Investigative journalism should be encouraged only through the legal frame work and this should be incorporated in the training courses by these media houses. The Press Council of India should have more teeth when it comes to decision making and sanctions. It should have a deterrent effect on the journalists. Without fear of law and the public the media might stride ahead into forbidden areas of national security on the pretext of right to information. A strong legislation is the need of the time which will fix the boundaries of press and privacy. In this world of increasing technology and lobbying by the media houses, an individual is left all alone and helpless with no means to protect him. In this position he cannot even defend himself. He is left all open and alone to abuses and shame for the sake of public interest, which the media claims is the freedom of press. Right to Privacy which is not Constitutional protected right should be balanced by the courts with right to press in tune with the UDHR of which India is a party.

\footnotetext{
86 'News for hire’ by Zubeda Hamid, The New Indian Express, dt. 4/12/2010, p.8.
} 